\title{
The e-Learning Method for Teaching Mathematical Content in the COVID-19 Era
}

\author{
Yersi Luis Huamán-Romaní, Dr. Antonio-José Moreno-Guerrero, Dr. José-Antonio \\ Marín-Marín; Dr. Jesús López-Belmonte \\ ${ }^{1}$ Academic Department of the Faculty of Engineering Economics, National Frontier University, \\ Sullana, Peru \\ ${ }^{2}$ Lecturer in the Department of Didactics and School Organisation, University of Granada, Ceuta, \\ Spain \\ ${ }^{3}$ Lecturer in the Department of Didactics and School Organisation, University of Granada, Granada, \\ Spain \\ ${ }^{4}$ Lecturer in the Department of Didactics and School Organisation, University of Granada, Ceuta, \\ Spain
}

Article History: Received: 10 November 2020; Revised 12 January 2021 Accepted: 27 January

2021; Published online: 5 April 2021

\begin{abstract}
The technological progress in the social field in a sudden way, specifically in the pedagogical field due to the spread of COVID-19, has had to force and use new teaching and learning strategies. As one of these many teaching processes is the method known as e-learning, which has become more valuable and very important in these times due to the rapid spread of the COVID-19 pandemic. The research method applied is descriptive, correlational, cross-sectional and predictive. The sample applied in this research is 608 students of the 5th grade of secondary education in the province of Sullana, Piura region of Peru. The results reveal the existence of a very significant influence in almost all the dimensions of the study. The dimensions with the highest association values are participation-autonomy, outcome resolution, decision concepts and decision outcomes. The dimensions with the lowest strength of association are undoubtedly the motivation rating, which can be interpreted as meaning that motivation does not have a strong influence on the results. It can be concluded that the application of the e-learning method in the teaching of 5th grade high school students in the area of mathematics is positively valued, although a strong incidence of the method on the grades is not observed, due to the fact that a lower percentage of students were unaware of the application of information and communication technologies for online learning. In addition, women tend to rate autonomy and participation more positively than men when the aforementioned teaching method is applied.
\end{abstract}

Keywords: ICT, educational innovation, educational technology, e-learning, mathematics, gender, age

\section{Introduction}

Society is advancing by leaps and bounds because of the progress of technology in daily tasks (Garzón et al., 2020), all this has meant a new stage in the life of every human being (Hinojo et al., 2019), aspects such as work, social and educational have been altered due to the development of infrastructure and technological equipment (López-Belmonte et al., 2020a; Moreno-Guerrero et al., 2021) and all this has benefited and more than anything else has facilitated the performance of various daily tasks of people (Maldonado, García \& Sampedro-Requena, 2019).

In the education sector, the evolution that technology has undergone is reflected in the implementation of information and communication technology (ICT) projects (Area, Hernández \& Sosa, 2016), this educational technology directly influences the training plans and instructional processes of the different educational stages (Moreno-Guerrero et al., 2020a). All this innovation implies new and better learning experiences, as well as the generation of new spaces in which they carry out teaching practices ( $\mathrm{Li}$ et al., 2019). ICT have caused that the spaces where these teaching and learning methods were traditionally carried out have changed (Pereira, Fillol \& Moura, 2019) abysmally, this technology that has been incorporated into teaching has caused the elimination of barriers regarding the space where the training act was carried out and the time or time slot reserved for teaching and learning (Marín-Marín et al., 2020a). Likewise, ICT has favored having the necessary information immediately (Nikopoulou, Akriotou \& Gialamas, 2019) and in different formats to suit the interested party (Moreno-Guerrero et al., 2020b). Likewise, educational technology has produced improvements in various 
psychoeducational aspects such as motivation to the world of digitalization of students (Álvarez-Rodríguez, Bellido-Márquez \& Atencia-Barrero, 2019), the technological and innovative impact has had repercussions on the autonomy and attitude of students to face a very important step in their teaching and learning according to the times we live in due to the continuous transformations, both methodological and resources used for teaching (López-Belmonte et al., 2021a; López-Belmonte et al., 2020b).

Among the pedagogical actions of innovative character is e-learning (Cole, Swartz \& Shelley, 2020), this didactic method is conceived as a purely online instruction process, through the Internet and electronic devices, allowing a training modality of synchronous or asynchronous character, from anywhere (Baby \& Kannammal, 2020), this teaching and learning methodology has been in use since 1993 (Yazdanfar et al., 2021), so it has a long history in the educational field (Hamutoglu, Savasci \& Sezen-Gultekin, 2019).

Currently, due to the pandemic situation caused by COVID-19, its use of the e-learning method in educational centers has increased (Mian \& Khan, 2020) thanks to the flexibility provided by this method for formative actions within learning (Qian, 2018), positioning it as one of the best instructional options suitable for these times, both for training and evaluation of students (Bayaga, 2021). However, to implement this learning process, electronic equipment is required (Zhu \& Chen, 2020) as well as to make innovations in learning spaces, various technological equipment and digital resources are required (Alhassan, 2020; Shakah, Al-Oqaily \& Alqudah, 2019). In this sense, the use of e-learning is postulated as a challenge, not only for the members of the educational community (Zhou, Zhao \& Zhang, 2020), but also for the general public and not only because of the technological requirements that are needed, but also because of the level of digital competence needed to be able to carry it out effectively (Aghababaeir \& Ardani, 2018).

The use of e-learning presents singularities that other teaching and learning methods do not have (Wongwuttiwat, Buraphadeja \& Tantontrakul, 2020), since it was conceived as the evolution of distance education (Sathiyamoorthi, 2020; Semerci \& Goularas, 2020) and is completely different from face-to-face education (Gerhatova, Perichta \& Palcut, 2020). In this sense, the use of the e-learning method presents several casuistry when applied in teaching and learning processes; these characteristics include promoting conversation and interaction among students; facilitating the development of group tasks; fostering peer relationships (Bakhouyi et al., 2019); promoting collaboration among students to achieve the same goals (Sathiyamoorthi, 2020); offering communication possibilities in synchronous or asynchronous time (Gunasinghe et al., 2019); favoring learning anywhere and anytime (Krzyszkowska \& Mavrommati, 2020); encouraging digital improvement (Mousavi et al., 2020); adapting to a new pace and level of learning (Mowla \& Kolekar, 2020); to promote students' motivation (Rakic et al., 2020); to facilitate the progress of the ability to learn and learn at their own pace (Chaka, Nkhobo \& Lephalala, 2020); so the teacher can also attend to the different peculiarities of the students (Waluyo, 2020); to provide the opportunity to reach an infinite number of pedagogical and didactic resources, which can favor and boost their learning (Mayer, 2020); to favor the continuous monitoring of the teaching and learning development by the teacher (Bheki, 2020); the teacher will make use of different digital and technological resources more familiar and friendlier to the students (Lam \& Dongol, 2020).

It is important to assume that e-learning method is not distance learning, e-learning method is a specific case of distance learning (Dong et al., 2020), where is the difference, firstly, distance learning makes use of e-mail to transmit the theoretical contents of a certain subject (Dwyer \& Walsh, 2020), in this case, distance learning does not have a virtual medium (Lazarova \& Lazarov, 2020). Secondly, the theoretical contents of distance learning are not interactive, these contents are abundant and theoretical in nature (Viktorova, 2020). Thirdly, the approach between the student and the teacher is punctual, the teacher is only a mere transmitter of the theoretical contents requested by the curriculum; the student is also a passive receiver (Chang et al., 2020).

In the case of e-learning, the opposite happens with distance learning. The pedagogical act can take place 24 hours a day, every day of the year (Ashwin \& Reddy, 2020). Training can take place and at any time, provided that a suitable technological device is available (Tan, Liew \& Gan, 2020). In this case, the student is an active recipient in this process, since the student structures the pedagogical act, trying to develop what is established in the didactic guide (Rajabalee \& Santally, 2020), the contents are not purely theoretical; they are usually interactive; in addition, students can access other resources available on the network (Ben, Abid \& Meddeb, 2020). Comparing e-learning and distance learning, it can be observed that there is a change of direction and perspective; in this case, the pedagogical perspective changes substantially (Vagarinho \& Llamas-Nistal, 2020) for the learner.

Although the e-learning method may have benefits for the learner, this method may have contraindications for teachers. In this case, it is always good to take them into account to minimize their possible impact (LópezBelmonte et al., 2020a). The e-learning method can lead to a space-time gap for teachers (Cerezo et al., 2020). To avoid this, it is necessary to offer personalized teaching environments, trying to motivate and encourage their own learning process and pace (Moubayed et al., 2020). Another counter-indication is the digital divide 
(Movchhun, Lushkov \& Pronkin, 2020), not all students have the same access to technological resources, causing inequality in the pedagogical act (Yaniawati et al., 2020).

In the field of science, where there is no continuous interaction of mathematics, mathematics is considered an indispensable tool to interpret the immediate environment and represent the various facts, whether scientific, technical and/or social, that occur in today's world (Williamson, 2018). In addition, mathematics facilitates the interpretation of social reality phenomena such as economic aspects or historical facts, among others (Carvajalino, 2018). This is how mathematics becomes a suitable and effective tool for acquiring knowledge, reflecting on social aspects and representing environmental facts (Acharjee, 2018). Specifically, mathematics uses a language that allows it to explain with detail and precision the phenomena that occur (Kartal \& Caglayan, 2018) in the ordinary events of life, which makes it possible to transform all these facts into coherent knowledge and information (Yagci \& Uluoz, 2018). This fact means that mathematics is considered as an instrumental subject, since laying the foundations for the acquisition of knowledge in other scientific fields such as political science or sociology are very important (Lewis et al., 2017). On the other hand, mathematics allows the development of the student's intellect, promoting entrepreneurship, the development of autonomy, creativity or the improvement of self-esteem and develop in the social and environmental (Paechter et al., 2017; Titilope \& Idiong, 2017).

The e-learning methodology has been used in various contexts and specifically for mathematics teaching (Ahn \& Edwin, 2018; Albano \& Dello, 2019) with significant results. In this sense, the application of the MCIEC model (motivation, context, interactivity, evaluation and connectivity) increases the student's ability to make an effort to understand mathematical content thanks to the greater motivation, interest and adaptation to the context that this model allows (Ahn \& Edwin, 2018). The studies consulted support the fact that the use of elearning in mathematics education leads to improvements if applied with an adequate teaching and learning method. Some examples are the development of the e-learning method combined with the GeoGebra resource, since it is integrated with the Moodle training platform and allows improving aspects such as motivation, assessment, increasing students' interest and adapting assessment to students' needs (Albano \& Dello, 2019). In the same line, another similar case can be the development of e-learning methodology through the working memory capacity method (CMMC); this method promotes an improvement of students' skills for the acquisition of various mathematical aspects that facilitates a better academic performance of students, this fact is due to the increase of their participation and motivation to work on mathematical contents (El Mamoun, Erradi \& El Mhouti, 2018). Another case of methodological integration is the e-learning method and Edmodo application in the field of mathematics, this combination enhances collaborative learning which, in turn, increases the application, understanding, memorization, analysis, evaluation and creation of mathematical content. Similarly, this conjunction increases students' attitude and acceptance of mathematical content (Nasrullah, Marlina \& Dwiyanti, 2018). A final example of pedagogical action using the e-learning method is the individualized elearning environment called UZWEBMAT, which allows personalized attention by adapting to the students' learning style and improving their comprehension skills; on the other hand, it also increases their responsibility in learning, which is reflected in academic performance and motivation (Ozyurt et al., 2013). These examples of methodological integration support the fact that the development of e-learning method is enhanced if it is applied with an appropriate teaching and learning method. In this sense, the application of e-learning in mathematics learning increases students' own participation and interest, improving their performance and acquisition of mathematical content (Mulqueeny et al., 2015).

On the other hand, it should be taken into account that the application and development of this type of teaching method can be negatively affected by facts such as poor connectivity, inflexible scheduling, or inadequate technological devices (Msomi \& Bansilal, 2018).

In the field of mathematics, there are no studies that analyze the influence or relationship between gender or age and the e-learning method. However, there are studies that relate the gender and age of students to the application of e-learning (Mutambik, Lee \& Almuqrin, 2020). In relation to gender, there are results that show that the existing reduction of the gender gap is occurring faster in more developed cities (Yawson, 2021). In other cases, it is observed that there are divergences between men and women when using the e-learning method, in this case, women may be anxious and men may enjoy this pedagogical method (Kanwal, Rehman y Asif, 2020). In addition, gender may affect attitudes towards learning when e-learning is used and this leads to differences in students' learning performance (Wongwatkit et al., 2020).

Regarding age, there are studies indicating that there are differences according to the age group (Djalev \& Bogdanov, 2019). Depending on the age, the e-learning method is classified better or worse, in many cases there is no agreement in the results of the studies applied so far (De Palo et al., 2018). 


\section{Justification and objectives of the study.}

The technological development of today's society (Marín-Marín et al., 2020b), together with the current pandemic situation resulting from COVID-19 (Kim, Kim \& Han, 2021), as well as the rise of innovative approaches (López-Belmonte et al., 2019) and the projection of distance learning platforms (Segura-Robles et al., 2020), have led to emerging methodologies such as e-learning reaching a number of potentialities in their different applications in the course of teaching and learning (López-Belmonte et al., 2021b), as well as the increase in the number of innovative experiences related to the course of mathematics at the educational levels that are being carried out as a consequence of the current situation that the educational systems are experiencing (Fuentes-Cabrera et al., 2020; Moreno-Guerrero et al., 2020c).

In order to carry out the research on the scope and use of the application of an innovative experience through the e-learning method for the teaching of mathematical contents in students of 5th level of secondary education in the region of Piura, province of Sullana in the country of Peru, the following objectives have been formulated:

-To analyze from a descriptive perspective the different dimensions included in the validation instrument with the sole purpose of knowing the students' appreciation of the use and application of the e-learning method in the teaching of the area of mathematics.

-To know the existing relationship and the level of correlation between the established dimensions.

-To discover if significant differences exist for each of the dimensions, both in terms of gender and age.

-To identify the effect caused by gender and age on the dimensions analyzed.

\section{Justification and objectives of the study.}

\subsection{Research design}

This research focused on a descriptive, correlational, cross-sectional and predictive research design, using a quantitative research methodology, based on expert considerations (Hernández, Fernández y Baptista, 2016).

\subsection{Sample}

A total of 608 students from various educational institutions in the region of Piura, exclusively from the province of Sullana, were surveyed; only students in the 5th year of secondary school participated. Specifically, the sample of students corresponds to the 5th grade of secondary education in private and state educational institutions. Of these students, $45.7 \%$ are male and $54.3 \%$ are female. These participants have a mean age of 16.39 years $(\mathrm{SD}=.715)$. The subject selected was from the area of mathematics through purposive sampling, due to the researchers' ease of access to various private and state educational institutions in the geographic context cited.

\subsection{Instrument}

A validated questionnaire (Moreno-Guerrero et al., 2020d) was used as an instrument for data collection. This questionnaire consists of 27 items. The different questions are articulated in different dimensions: a) Socioeducational (3); b) Motivation (2); c) Autonomy (2); d) Collaboration (2); e) Participation (2); f) Resolution (2); g) Class time (2); h) Concepts (2); i) Scientific data (2); j) Graphs (2); k) Learning outcomes (2); l) Decisionmaking (2); m) Classifications (2). This tool is configured with a 5-point Likert-type response scheme (1- most negative rating, 5 -most positive rating).

This instrument achieved adequate ratings in its original validation process by its authors. This consisted first of all in revising all the items of the original questionnaire to adapt the vocabulary to the Peruvian context. Once the questionnaire was revised, the respective validation was carried out. An exploratory factor analysis was performed, using a varimax rotation. Tests were performed, such as Bartlett's test of sphericity (2863.52; $\mathrm{p}<0.001)$ to determine the dependence between variables and the Kaiser-Meyer-Olkin test $(0.87)$ to reveal the adequacy of the sample, obtaining adequate results in both tests. In addition, several statistics were used to reveal the reliability of the tool, such as Cronbach's alpha coefficient $(\alpha=0.89)$, composite reliability $(\mathrm{CR}=$ $0.83)$ and mean variance extracted $(\mathrm{MVE}=0.84)$. In all of them, results relevant to the internal consistency of the questionnaire were achieved.

\subsection{Procedure and data analysis}

The study began in the last quarter of 2020. This research covered different state and private schools in the province of Sullana in Peru. Access to the sample was intentional. All participants were explained the purpose 
of the research and ratified their consent to participate in the study surveys. At all times, the ethical considerations of good research practices established in the Declaration of Helsinki were respected.

At the didactic level, an innovative experience was carried out using an e-learning approach to learn mathematical content. The didactics consisted of a total of 24 sessions, developed through the "I learn at home" program implemented by the Peruvian State for education due to the situation generated by Covid-19. This training program was broadcast twice a week for 34 weeks (for students in the fifth grade of secondary school), which was transmitted on open television, radio and Internet with free access especially for students in state educational institutions, while private educational institutions used Moodle platforms. The teachers of the students in the area of mathematics whose only case study is the 5th grade of secondary education prepared learning cards for reinforcements with topics that were touched in the classes heard through the State program, to then provide academic reinforcements in schedules established by mutual agreement and each student was given the learning cards for their respective teaching-learning; this was done using the means of Technology, Information and Communication. Once the different sessions were held, the data sampling process was carried out with the application of the questionnaire, using the google forms tool made up of twenty-seven (27) questions with Likert-type answers. Once all the information was collected, a statistical analysis was carried out in order to reach pertinent conclusions that would allow us to achieve the different objectives and answer the different questions formulated.

The descriptive statistical analysis was carried out with the IBM SPSS version 25 program. First, the assumptions of linearity, independence, normality, homoscedasticity, residual analysis and non-collinearity were tested to determine the validity of the application of the statistical model, based on the assumptions revealed by the assumptions, parametric tests were chosen (Montilla \& Kromrey, 2010).

A descriptive study was performed to reveal the distribution of variables, using statistics such as mean (M), standard error of measurement (SEM), standard deviation (SD), coefficient of variation (CV), skewness (Skw) and kurtosis (Kme). Bivariate Pearson correlations were also performed in order to reflect the statistical significance in the linear association between the different variables, as well as their strength and direction. Student's t-test was then calculated as a descriptive measure for comparison of means to detect statistically significant differences. Finally, multiple linear regression was performed using the stepwise and stepwise method to provide information on the dependence between variables.

\section{Results.}

Regarding the results achieved in the statistical study, it can be indicated that the mean rating is slightly above the overall mean, which is 2.5 . This shows a positive evaluation by the students in the development of the teaching and learning process. All averages are above 3 . Of all the dimensions, the one with the lowest average is grades. On the other hand, the one with the highest average is participation and decision. Continuing with the analysis, and taking into account (Jöreskong, 2001), the data distributions follow a normal curve, given that the skewness values are between -1.96 and +1.96 . This justifies the various statistical analyses that follow. In other words, it justifies the use of parametric tests. Furthermore, the use of parametric tests is reinforced by the values obtained for the coefficient of variance, which are below 0.3. The kurtosis of each of the dimensions is variable, with platykurtic, mesokurtic and leptokurtic kurtosis (Table 1).

Table 1. Descriptive statistics of the dimensions analyzed

\begin{tabular}{lllllll}
\hline Dimensions & $\mathrm{M}$ & SEM & SD & CV & $\mathbf{S}_{\mathbf{k w}}$ & $\mathbf{K}_{\mathbf{m e}}$ \\
\hline Motivation & 3.41 & .034 & .85 & .249 & -.339 & .185 \\
\hline Autonomy & 3.62 & .036 & .88 & .245 & -.452 & -.099 \\
\hline Collaboration & 3.42 & .034 & .83 & .244 & -.181 & -.058 \\
\hline Participation & 3.69 & .038 & .94 & .257 & -.562 & -.078 \\
\hline Resolution & 3.51 & .033 & .83 & .238 & -.357 & -091 \\
\hline Class-time & 3.50 & .034 & .86 & .246 & -.307 & -.045 \\
\hline Concepts & 3.57 & .036 & .89 & .251 & -.468 & -.018 \\
\hline Scientific data & 3.50 & .034 & .83 & .239 & -.293 & -.009 \\
\hline Graphics & 3.55 & .036 & .89 & .252 & -.451 & .020 \\
\hline Results & 3.62 & .034 & .84 & .234 & -.368 & .089 \\
\hline Decision & 3.69 & .037 & .91 & .247 & -.586 & .095 \\
\hline Ratings & 3.13 & .022 & .55 & .177 & -.277 & -.177 \\
\hline
\end{tabular}


Note: $\mathrm{M}=$ =mean; $\mathrm{SEM}=$ Standard error of the mean; $\mathrm{SD}=\mathrm{Standard}$ deviation; $\mathrm{CV}=$ Coefficient of variance; $\mathrm{S}_{\mathrm{kw}}=$ Asymmetry; $\mathrm{K}_{\mathrm{me}}=$ Kurtosis.

The correlations established between the various dimensions of the study show a highly significant relationship between all of them. The strength of association established is medium in most cases, with some dimensions having medium-high, medium-low and even low strength of association. This indicates that all the dimensions applied in the study are related to each other, which reinforces that the development and application of the e-learning method in mathematics teaching generates improvements in all dimensions. The dimensions that have acquired the highest values of association are participation-autonomy, outcome resolution, decision concepts, and decision outcomes. From these data it can be determined that there is a direct influence between outcome resolution and students' decisions. On the other hand, the dimensions with the lowest strength of association are undoubtedly the motivation ratings, where the values are below 0.2 . In this case, it can be interpreted that there is no strong influence of motivation on outcomes (Table 2).

Table 2. Correlations of all variables.

\begin{tabular}{|c|c|c|c|c|c|c|c|c|c|c|c|}
\hline DIM & MOT & AUT & $\mathrm{COL}$ & PAR & RES & CLA & $\mathrm{CON}$ & SCI & GRA & RSL & DEC \\
\hline \multicolumn{12}{|l|}{ MOT } \\
\hline AUT & $.437 * *$ & & & & & & & & & & \\
\hline $\mathrm{COL}$ & $.333^{* *}$ & $.489 * *$ & & & & & & & & & \\
\hline PAR & $.386 * *$ & $.633 * *$ & $.483 * *$ & & & & & & & & \\
\hline RES & $.359 * *$ & $.519 * *$ & $.475 * *$ & $.510 * *$ & & & & & & & \\
\hline CLA & $.277 * *$ & $.413 * *$ & $.465 * *$ & $.488 * *$ & $.424 * *$ & & & & & & \\
\hline $\mathrm{CON}$ & $.339 * *$ & $.563 * *$ & $.445 * *$ & $.607 * *$ & $.580 * *$ & $.491 * *$ & & & & & \\
\hline SCI & $.351 * *$ & $.433 * *$ & $.492 * *$ & $.494 * *$ & $.560 * *$ & $.484 * *$ & $.572 * *$ & & & & \\
\hline GRA & $.365 * *$ & $.478 * *$ & $.455 * *$ & $.469 * *$ & $.541 * *$ & $.496 * *$ & $.572 * *$ & $.560 * *$ & & & \\
\hline RSL & $.362 * *$ & $.494 * *$ & $.476 * *$ & $.511 * *$ & $.634 * *$ & $.523 * *$ & $.587 * *$ & $.583 * *$ & $.611 * *$ & & \\
\hline DEC & $.330 * *$ & $.552 * *$ & $.427 * *$ & $.592 * *$ & $.565 * *$ & $.496 * *$ & $.636^{* *}$ & $.596^{* *}$ & $.539 * *$ & $.641 * *$ & \\
\hline RAT & $.182 * *$ & $.296 * *$ & $.280 * *$ & $.367 * *$ & $.299 * *$ & $.280 * *$ & $.338 * *$ & $.242 * *$ & $.327 * *$ & $.307 * *$ & $.326 * *$ \\
\hline
\end{tabular}

Note: DIM=Dimensions; MOT= Motivation; AUT=Autonomy; $\mathrm{COL}=$ Collaboration; $\mathrm{PAR}=\mathrm{Participation}$; RES=Resolution; CLA=Class-time; $\mathrm{CON}=$ Concepts; $\mathrm{SCI}=$ Scientific-data; GRA=Graphics; RSL=Results; DEC=Decision; RAT=Ratings.

$\mathrm{N}=608$

**. The correlation is significant at the 0.01 level (bilateral)

Table 3 shows the relationship between gender, on the one hand, and age, on the other, with the various dimensions of the study. For this, the Student's t-test for independent samples has been used. It should be noted that, for age, given the large difference in the sample between the different ages, these have been grouped into two large groups. On the one hand, those under 16 years of age and the other group over 17 years of age. Starting with gender, it can be determined that there are no significant differences between men and women in most of the dimensions. In the dimensions where there are significant differences are autonomy and participation. In both cases, women have shown a higher value than men in this regard. Continuing with the age analysis, the survey results reveal that there are no significant differences in any dimension according to age. In other words, the scores for each of the dimensions are not altered by the age of the students.

Table 3. Differentiated results according to gender and age of the students in each of the dimensions analyzed

\begin{tabular}{|c|c|c|c|c|c|c|}
\hline GENDER & & & & & & \\
\hline \multirow{3}{*}{ Motivation } & Gender & $\mathrm{n}$ & $\mathrm{M}$ & SD & $\mathrm{t}$ & $\mathrm{p}$ \\
\hline & $\mathrm{H}$ & 278 & 3.40 & .866 & \multirow[t]{2}{*}{-.268} & \multirow[t]{2}{*}{.789} \\
\hline & $\mathrm{M}$ & 330 & 3.31 & .839 & & \\
\hline \multirow[t]{2}{*}{ Autonomy } & $\mathrm{H}$ & 278 & 3.52 & .903 & \multirow[t]{2}{*}{-2.598} & \multirow[t]{2}{*}{.010} \\
\hline & $\mathrm{M}$ & 330 & 3.71 & .869 & & \\
\hline \multirow[t]{2}{*}{ Collaboration } & $\mathrm{H}$ & 278 & 3.38 & .853 & \multirow[t]{2}{*}{-1.273} & \multirow[t]{2}{*}{.204} \\
\hline & $\mathrm{M}$ & 330 & 3.46 & .825 & & \\
\hline \multirow[t]{2}{*}{ Participation } & $\mathrm{H}$ & 278 & 3.58 & .916 & \multirow[t]{2}{*}{-2.768} & \multirow[t]{2}{*}{.006} \\
\hline & $\mathrm{M}$ & 330 & 3.79 & .966 & & \\
\hline \multirow[t]{2}{*}{ Resolution } & $\mathrm{H}$ & 278 & 3.45 & .832 & \multirow[t]{2}{*}{-1.734} & \multirow[t]{2}{*}{.084} \\
\hline & $\mathrm{M}$ & 330 & 3.57 & .838 & & \\
\hline Class-time & $\mathrm{H}$ & 278 & 3.47 & .886 & -.614 & .539 \\
\hline
\end{tabular}




\begin{tabular}{|c|c|c|c|c|c|c|}
\hline & $\mathrm{M}$ & 330 & 3.51 & .839 & & \\
\hline \multirow[t]{2}{*}{ Concepts } & $\mathrm{H}$ & 278 & 3.51 & .919 & \multirow[t]{2}{*}{-1.453} & \multirow[t]{2}{*}{.147} \\
\hline & $\mathrm{M}$ & 330 & 3.62 & .879 & & \\
\hline \multirow[t]{2}{*}{ Scientific-data } & $\mathrm{H}$ & 278 & 3.48 & .839 & \multirow[t]{2}{*}{-.595} & \multirow[t]{2}{*}{.552} \\
\hline & $\mathrm{M}$ & 330 & 3.52 & .840 & & \\
\hline \multirow{2}{*}{ Graphics } & $\mathrm{H}$ & 278 & 3.48 & .894 & \multirow{2}{*}{-1.623} & \multirow[t]{2}{*}{.105} \\
\hline & $\mathrm{M}$ & 330 & 3.60 & .897 & & \\
\hline \multirow[t]{2}{*}{ Results } & $\mathrm{H}$ & 278 & 3.61 & .860 & \multirow[t]{2}{*}{-.193} & \multirow[t]{2}{*}{.847} \\
\hline & $\mathrm{M}$ & 330 & 3.63 & .842 & & \\
\hline \multirow[t]{2}{*}{ Decision } & $\mathrm{H}$ & 278 & 3.65 & .934 & \multirow[t]{2}{*}{-1.187} & \multirow[t]{2}{*}{.236} \\
\hline & $\mathrm{M}$ & 330 & 3.73 & .896 & & \\
\hline \multirow[t]{2}{*}{ Ratings } & $\mathrm{H}$ & 278 & 3.10 & .577 & \multirow{2}{*}{-1.452} & \multirow[t]{2}{*}{.147} \\
\hline & $\mathrm{M}$ & 330 & 3.16 & .531 & & \\
\hline \multicolumn{7}{|l|}{$\mathrm{AGE}$} \\
\hline & Age & $\mathrm{n}$ & $\mathrm{M}$ & SD & $\mathrm{t}$ & $\mathrm{p}$ \\
\hline \multirow[t]{2}{*}{ Motivation } & $-=16$ & 375 & 3.41 & .833 & \multirow[t]{2}{*}{.177} & \multirow[t]{2}{*}{.860} \\
\hline & $+=17$ & 233 & 3.40 & .881 & & \\
\hline \multirow[t]{2}{*}{ Autonomy } & $-=16$ & 375 & 3.62 & .889 & \multirow{2}{*}{.152} & \multirow{2}{*}{.879} \\
\hline & $+=17$ & 233 & 3.61 & .890 & & \\
\hline \multirow[t]{2}{*}{ Collaboration } & $-=16$ & 375 & 3.43 & .828 & .132 & .895 \\
\hline & $+=17$ & 233 & 3.42 & .857 & & \\
\hline Participation & $-=16$ & 375 & 3.69 & .965 & -.204 & .839 \\
\hline & $+=17$ & 233 & 3.70 & .942 & & \\
\hline Resolution & $-=16$ & 375 & 3.51 & .803 & -.047 & .962 \\
\hline & $+=17$ & 233 & 3.51 & .890 & & \\
\hline Class-time & $-=16$ & 375 & 3.45 & .853 & -1.601 & .110 \\
\hline & $+=17$ & 233 & 3.57 & .869 & & \\
\hline Concepts & $-=16$ & 375 & 3.56 & .898 & -.313 & .755 \\
\hline & $+=17$ & 233 & 3.59 & .901 & & \\
\hline Scientific-data & $-=16$ & 375 & 3.49 & .812 & -.500 & .617 \\
\hline & $+=17$ & 233 & 3.52 & .884 & & \\
\hline Graphics & $-=16$ & 375 & 3.55 & .894 & .042 & .966 \\
\hline & $+=17$ & 233 & 3.55 & .803 & & \\
\hline Results & $-=16$ & 375 & 3.62 & .832 & -.105 & .917 \\
\hline & $+=17$ & 233 & 3.62 & .878 & & \\
\hline Decision & $-=16$ & 375 & 3.71 & .904 & .444 & .657 \\
\hline & $+=17$ & 233 & 3.67 & .931 & & \\
\hline Ratings & $-=16$ & 375 & 3.12 & .557 & $\begin{array}{l}-.666 \\
\end{array}$ & .505 \\
\hline & $t=17$ & 233 & 3.12 & .547 & & \\
\hline
\end{tabular}

Note: $\mathrm{n}=$ sample; $\mathrm{M}=$ mean; $\mathrm{SD}=$ standard deviation; $\mathrm{t}=$ Student's $\mathrm{t}-\mathrm{value} ; \mathrm{p}=\mathrm{p}$ value.

Table 4 shows the results after application of the multiple linear regression model. In this case, we have tried to identify the effect of both gender and age on the different dimensions of the study. On the one hand, for gender, it is shown how, by means of the successive steps technique, an explanatory model is obtained that explains only $0.01 \%$ of it. This indicates that a slight influence of gender is glimpsed in the different dimensions of the study, with a very weak strength, when the e-learning method is applied in the teaching of mathematics. On the other hand, with respect to age, the stepwise model was not applied, since no explanatory model was generated. The technique used is that of introduction, in order to provide the resulting data. In this case, it can be stated that age has no effect on the development of the e-learning method in students.

Table 4. Multiple regression model by gender and age.

\begin{tabular}{|c|c|c|c|c|c|c|c|}
\hline \multicolumn{8}{|c|}{ GENDER (next steps) } \\
\hline Model & $\mathrm{R}$ & $\mathrm{R}^{2}$ & $\mathrm{R}^{2} \mathrm{C}$ & ETE & $\mathrm{CR}^{2}$ & $\mathrm{CF}$ & SCF \\
\hline 1 & .112 & .012 & .011 & .496 & .012 & 7.662 & .006 \\
\hline \multicolumn{8}{|c|}{ AGE (introduce) } \\
\hline Model & $\mathrm{R}$ & $\mathrm{R}^{2}$ & $\mathrm{R}^{2} \mathrm{C}$ & ETE & $\mathrm{CR}^{2}$ & $\mathrm{CF}$ & SCF \\
\hline 1 & .102 & .010 & -.009 & .641 & .010 & .525 & .899 \\
\hline
\end{tabular}


Note: R=R-statistic; R2=R-squared R-statistic; R2C=Corrected R-squared R-statistic; ETE= Standard Error of Estimate; $\mathrm{CR} 2=$ Change in $\mathrm{R} 2, \mathrm{CF}=$ Change in $\mathrm{F} ; \mathrm{SCF}=\mathrm{Sig}$. Change in $\mathrm{F}$.

Finally, observing the resulting explanatory model of gender, it can be indicated that the gender of the participants can generate an explanation of the model, based on the dimension of participation. The values show that the influence is very low, but sufficient to be considered and taken into account as a predictive capacity in the application of the e-learning method in the teaching of mathematics (Table 5).

Table 5. Coefficients of the multiple linear regression model.

\begin{tabular}{llllll}
\hline GENDER & \multicolumn{1}{l}{} & \\
\hline 1 (Constant) & $\mathrm{B}$ & TE & $\mathrm{Be}$ & $\mathrm{t}$ & $\mathrm{S}$ \\
\hline Participation & .059 & .021 & .112 & 2.768 & .006 \\
\hline
\end{tabular}

Note: $\mathrm{B}=\mathrm{Beta}$ (unstandardized coefficient); $\mathrm{TE}=\mathrm{Typ}$ ical error; $\mathrm{Be}=\mathrm{Beta}$ (standardised coefficient); $\mathrm{t}=\mathrm{T}$-statistic; $\mathrm{S}=$ Significant.

\section{Discussion.}

In the field of education with COVID-19 presence, ICTs have burst into educational practice, facilitating the adoption of innovative educational actions. These technologies have made it possible to eliminate the spatiotemporal barriers that have characterized traditional teaching (Marín-Marín et al., 2020a) and, consequently, have facilitated the emergence of methodologies such as e-learning. This teaching-learning methodology has an extensive background (Hamutoglu et al., 2019; Yazdanfar et al., 2021) that has facilitated the adoption of various resources and technologies specific to this methodology during the COVID-19 pandemic. The benefits of this methodology (Bayaga, 2021; Qian, 2018), together with the need to offer training adapted to the circumstances of home confinement, has facilitated a high increase in the number of educational centers (Mian $\&$ Khan, 2020). Thus, in the context of mathematics education, e-learning has been used for some time with very positive results (Albano \& Dello, 2019; Ozyurt et al., 2013). In the present case, and taking into account the results of the previous section, it can be seen that the average evaluation of the experience is around 3.5 in almost all cases, which indicates that the average evaluation of the students on the application of e-learning is in a high average position. In the same vein, and in relation to the different dimensions evaluated, the most highly valued dimension is participation and decision-making. This fact corroborates the results of other research in which, following the implementation of innovative pedagogical models in which students are at the center of the training process, their involvement and decision-making in the teaching and learning processes is reinforced, which were already demonstrated in other specific e-learning studies (Bakhouyi et al., 2019; Mousavi et al., 2020; Rakic et al., 2020; Waluyo, 2020). In the opposite case, the least valued dimension is the qualifications. This assessment coincides with other studies of similar characteristics (Chaka, Nkhobo y Lephalala, 2020; Mowla \& Kolekar, 2020; Waluyo, 2020) in which the learner's rating is not greatly affected. The interpretation of this effect is that the application of the e-learning pedagogical method in mathematics teaching should not lead to improvements in student ratings (Ahn \& Edwin, 2018; Ozyurt et al., 2013).

The results of the study reveal that the distribution of the data is normal, which shows that there is a homogeneous perception of the student body on the application of the e-learning method in mathematics teaching. On the other hand, a very significant influence was detected among all the dimensions of the study, which shows that the application of the e-learning method affects all the dimensions analyzed, although with different degrees of association (Moubayed et al., 2020). In this case, the dimensions participation-autonomy, results-resolution, decision-concepts and decision-results obtain higher values of association, suggesting a direct influence between the results with respect to the students' resolution and decisions. On the other hand, the lower strength of association between the motivation-grading dimensions can be interpreted as meaning that there is no strong influence of motivation on the results.

In relation to gender, the study reveals the influence between the application of the e-learning method (El Mamoun, Erradi \& El Mhouti, 2018) and mathematics teaching. As a specific case, it is observed that the dimensions autonomy and participation in women tend to be more valued than in men. In the rest of the dimensions, this variable does not have a significant impact. However, gender can influence student participation when the e-learning pedagogical method is implemented in the teaching and/or reinforcement of mathematics courses. On the issue of the age variable, the results of the study show that there is no effect between this variable and the implementation of the e-learning method and the teaching of mathematics. This reinforces the idea that age is not a fact that affects the opinion of students on the implementation of the method in any of its dimensions and, therefore, does not generate any influence on the e-learning pedagogical method in the teaching of mathematics (Mulqueeny et al., 2015; Nasrullah, Marlina \& Dwiyanti, 2018). 


\section{Conclusions.}

In conclusion, the application of the e-learning method in the teaching of mathematics with students in the 5th grade of secondary education is positively valued by the students themselves, although a high incidence of the pedagogical method is observed in the students' evaluations. In addition, women tend to value autonomy and participation more positively than men when the indicated pedagogical method is applied. This fact shows that gender can be an explanatory variable for the level of student participation when the pedagogical method is applied. On the other hand, the age of the student body is not revealed as a determinant in any aspect evaluated when applying the e-learning method in the teaching of mathematics.

The limitations of this research are mainly related to the selection of the sample. The sample did not follow a specific sampling technique and focused on convenience sampling. Another limitation may be related to the fact of obtaining the sample in pandemic time, which required a greater effort and could have been biased. In the same sense, these socio-sanitary circumstances made it difficult to obtain the pertinent permits from the different educational institutions, since it was not possible to go personally to the centers to obtain them.

As for future lines of research, it should be noted that it would be advisable to promote new e-learning programs in other subjects and contents in which students are offered the possibility of developing the dimensions that have been evaluated in this study and promoting more autonomous learning. This may be intrinsically related to the need for students to achieve the necessary competencies that motivate them to use the knowledge acquired in real contexts, enabling them to participate actively and responsibly in society.

In terms of implications, this research has practical contradictions of benefit to various sectors related to the field of education. From teachers, researchers and students, to entities and institutions delegated to the teaching of mathematics and the development of innovative educational tools. Among the conclusions more focused on teaching practice, the possibilities of e-learning for teaching mathematics can be extrapolated to other subjects. This would allow students to develop skills such as autonomy, problem solving not only of the mathematical type, active participation and decision making inside and outside society, so important for the development of the individual and his ability to interact in society. Moreover, as a consequence of the rise of technology in the new teaching and learning processes, and more specifically in the current pandemic, this study endorses the pedagogical model of e-learning as an effective approach that offers a real and feasible answer for students to continue their learning and training at home.

Last but not least, this methodology can be complemented by other emerging technologies in the educational world such as artificial intelligence. This association will allow the creation and development of electronic resources that help promote more complete learning, without neglecting the need for real interaction between the student and the teacher. All this will lead to the development of training actions that will improve the teaching-learning processes with the use of technology and the e-learning method.

Finally, the results show that this methodology can serve as a model for educational entities and institutions that develop training actions as a reference for the implementation of distance courses and the design of digital applications for training.

\section{References}

[1]. Acharjee, S. (2018). On Connections of Soft Set Theory with Existing Mathematics of Uncertainties: A Short Discussion for Non-Mathematicians with Respect to Soft Set Theory. New Math. Nat. Comput., 14(1), 1-9. Doi: 10.1142/S1793005718500011

[2]. Aghababaei, M., \& Ardani, S. (2018). Trend of Changes in E-learning Role in Identity Changes, Achievement Emotions and Attitude Toward School Between High School Students from Smart and Traditional Schools. Mod. J. Lang. Teach. Methods, 8(10), 570-586

[3]. Ahn, J.Y., \& Edwin, A. (2018). An e-Learning Model for Teaching Mathematics on an Open Source Learning Platform. Int. Rev. Res. Open Distrib. Learn., 19(5), 255-267. Doi: 10.19173/irrodl.v19i5.3733

[4]. Albano, G., \& Dello, U. (2019). GeoGebra in e-learning environments: A possible integration in mathematics and beyond. J. Ambient Intell. Humaniz. Comput., 10, 4331-4343. Doi: 10.1007/s12652018-1111-x

[5]. Alhassan, R.K. (2020). Assessing the preparedness and feasibility of an e-learning pilot project for university level health trainees in Ghana: a cross-sectional descriptive survey. BMC Medical Education, 20, 1-10. Doi: 10.1186/s12909-020-02380-2

[6]. Álvarez-Rodríguez, M.D., Bellido-Márquez, M.D., \& Atencia-Barrero, P. (2019). Teaching though ICT in Obligatory Secundary Education. Analysis of online teaching tools. RED, 19(59), 1-19. Doi: $10.6018 / \mathrm{red} / 59 / 05$ 
[7]. Area, M., Hernández, V., \& Sosa, J.J. (2016). Modelos de integración didáctica de las TIC en el aula. Comunicar, 24(47), 79-87. Doi: 10.3916/C47-2016-08

[8]. Ashwin, T.S., \& Reddy, R.M. (2020). Impact of inquiry interventions on students in e-learning and classroom environments using affective computing framework. USER Modeling User-Adapt. Interact., 30, 1-43. Doi: 10.1007/s11257-019-09254-3

[9]. Baby, A., \& Kannammal, A. (2020). Network Path Analysis for developing an enhanced TAM model: A user-centric e-learning perspective. Comput. Hum. Behav., 107, 1-7. Doi: 10.1016/j.chb.2019.07.024

[10]. Bakhouyi, A., Dehbi, R., Banane, M., \& Talea, M. (2019). A Semantic Web Solution for Enhancing The Interoperability of E-learning Systems by Using Next Generation of SCORM Specifications. Int. J. Emerg. Technol. Learn., 14(11), 174-185

[11]. Bayaga, A. (2021). Academics' views of adaptive e-learning technology in a South African university. International Journal of Technology Enhanced Learning, 13(1), 78-91. doi: 10.1504/IJTEL.2021.111592

[12]. Ben, A., Abid, M., \& Meddeb, A. (2020). Secure Fog-Based E-Learning Scheme. IEEE Access, 8, 31920-31933. Doi: 10.1109/ACCESS.2020.2973325

[13]. Bheki, C. (2020). Is Moodle or WhatsApp the preferred e-learning platform at a South African university? First-year students' experiences. Educ. Inf. Technol., 25(1), 927-941. Doi: 10.1007/s10639019-10005-5

[14]. Carvajalino, J. (2018). Edwin Bidwell Wilson and Mathematics as Language. ISIS, 109(3), 494-514. Doi: $10.1086 / 700016$

[15]. Cerezo, R., Bogarin, A., Esteban, M., \& Romero, C. (2020). Process mining for self-regulated learning assessment in e-learning. J. Comput. High. Educ., 32, 1-15. Doi: 10.1007/s12528-019-09225-y

[16]. Chaka, C., Nkhobo, T., \& Lephalala, M. (2020). Leveraging Moya(MA), WhatsApp and Online Discussion Forum to Support Students at an Open and Distance e-Learning University. Electronic Journal of E-learning, 18(6), 494-515. Doi: 10.34190/JEL.18.6.003

[17]. Chang, I.C., Lin, C.Y., Wen, C.H., Lo, H.K., \& Ho, T.J. (2020). Students' intention to use a 3D elearning platform in traditional Chinese medicine education. Interactive Learning Environments, 28(8), 991-1002. Doi: 10.1080/10494820.2018.1552875

[18]. Cole, M.T., Swartz, L.B., \& Shelley, D.J. (2020). Threaded Discussion: The Role It Plays in ELearning. Int. J. Inf. Commun. Technol. Educ., 16(1), 16-29. Doi: 10.4018/IJICTE.2020010102

[19]. De Palo, V., Limone, P., Monacis, L., Ceglie, F., \& Sinatra, M. (2018). Enhancing e-learning in old age. Australasian Journal of Adult Learning, 58(1), 88-109

[20]. Djalev, L., \& Bogdanov, S. (2019). Age and gender differences in evaluation the pedagogical usability of e-learning materials. English Studies at NBU, 5(2), 169-189. Doi: 10.33919/esnbu.19.2.0

[21]. Dong, L., Gao, T.T., Zheng, W., Zeng, K.B., \& Wu, X.S. (2020). E-Learning for Continuing Medical Education of Neurology Residents. Mind Brain and Education, 15(1), 1-6. Doi: 10.1111/mbe.12271

[22]. Dwyer, C.P., \& Walsh, A. (2020). An exploratory quantitative case study of critical thinking development through adult distance learning. ETR\&D-Educ. Technol. Res. Dev., 68, 17-35. Doi: 10.1007/s11423-019-09659-2

[23]. El Mamoun, B., Erradi, M., \& El Mhouti, A. (2018). Using an Intelligent Tutoring System to Support Learners' WMC in e-learning: Application in Mathematics Learning. Int. J. Emerg. Technol. Learn., 13(12), 142-156

[24]. Fuentes-Cabrera, A., Parra-González, M.E., López-Belmonte, J., \& Segura-Robles, A. (2020). Learning Mathematics with Emerging Methodologies-The Escape Room as a Case Study. Mathematics, 8(9), 1586. Doi: 10.3390/math8091586

[25]. Garzón, E., Sola, T., Ortega, J.L., Marín-Marín, J.A., \& Gómez, G. (2020). Teacher Training in Lifelong Learning - The Importance of Digital Competence in the Encouragement of Teaching Innovation. Sustainability, 12(7), 2852. Doi: 10.3390/su12072852.

[26]. Gerhatova, Z., Perichta, P., \& Palcut, M. (2020). Project-Based Teaching of the Topic "Energy Sources" in Physics via Integrated e-Learning - Pedagogical Research in the 9th Grade at Two Primary Schools in Slovakia. Education Science, 10(12), 1-18. Doi: 0.3390/educsci10120371

[27]. Gunasinghe, A., Abd Hamid, J., Khatibi, A., \& Azam, S.M.F. (2019). The adequacy of UTAUT-3 in interpreting academician's adoption to e-Learning in higher education environments. Interact. Technol. Smart Educ., 17(1), 86-106. Doi: DOI 10.1108/ITSE-05-2019-0020

[28]. Hamutoglu, N.B., Savasci, M., \& Sezen-Gultekin, G. (2019). Digital Literacy Skills and Attitudes towards E-learning. J. Educ. Future, 16, 93-107. Doi: 10.30786/jef.509293

[29]. Hernández, R., Fernández, C., \& Baptista, P. (2016). Metodología de la Investigación, 6th Ed.; MC Graw Hill Education: Mexico.

[30]. Hinojo, F.J., Aznar, I., Romero, J.M., \& Marín, J.A. (2019). Influencia del aula invertida en el rendimiento académico. Una revisión sistemática. Campus Virtuales, 8(1), 9-18 
[31]. Jöreskog, K.G. (2001). Analysis of ordinal variables 2: Cross-Sectional Data. In Structural Equation Modelling with Lisrel 8.51; Friedrich-Schiller-University Jena: Jena, Germany. pp. 116-119

[32]. Kanwal, F., Rehman, M., \& Asif, M.M. (2020). E-Learning Adoption and Acceptance in Pakistan: Moderating Effect of Gender and Experience. Mehran University Research Journal on Engineering and Technology, 39(2), 324-341. Doi: 10.22581/muet1982.2002.09

[33]. Kartal, A., \& Caglayan, K.T. (2018). A Buchet from Disciplines: SSSM (Social Sciences-ScienceMathematics). Egitim ve Bilim-Educ. Sci., 43(196), 189-214. Doi: 10.15390/EB.2018.7565

[34]. Kim, E.-J., Kim, J.J., \& Han, S.-H. (2021). Understanding Student Acceptance of Online Learning Systems in Higher Education: Application of Social Psychology Theories with Consideration of User Innovativeness. Sustainability, 13(2), 896. Doi: 10.3390/su13020896

[35]. Krzyszkowska, K., \& Mavrommati, M. (2020). Applying the Community of Inquiry e-Learning Model to Improve the Learning Design of an Online Course for In-service Teachers in Norway. Electronic Journal of E-learning, 18(6), 462-475. Doi: 10.34190/JEL.18.6.001

[36]. Lam, T.Y., \& Dongol, B. (2020). A blockchain-enabled e-learning platform. Interact. Learn. Environ., 1-23. Doi: 0.1080/10494820.2020.1716022

[37]. Lazarova, S., \& Lazarov, L. (2020). Distance Learning-Challenges and ways to achieve higher quality of training courses. Pedagog. -Pedagog., 92, 323-341

[38]. Lewis, K.L., Stout, J.G., Finkelstein, N.D., Pollock, S.J., Miyake, A., Cohen, G.L., \& Ito, T.A. (2017). Fitting in to Move Forward: Belonging, Gender, and Persistence in the Physical Sciences, Technology, Engineering, and Mathematics (pSTEM). Psychol. Women Q., 4l(4), 420-436. Doi: $10.1177 / 0361684317720186$

[39]. Li, S., Yamaguchi, S., Sukhbaatar, J., \& Takada, J. (2019). The Influence of Teachers' Professional Development Activities on the Factors Promoting ICT Integration in Primary Schools in Mongolia. Educ. Sci., 9(2), 78-86. Doi: 10.3390/educsci9020078

[40]. López-Belmonte, J., Fuentes-Cabrera, A., López-Núñez, J.A., Pozo-Sánchez, S. (2019). Formative Transcendence of Flipped Learning in Mathematics Students of Secondary Education. Mathematics, 7(12), 1226. Doi: 10.3390/math7121226

[41]. López-Belmonte, J., Marín-Marín, J.A., Soler-Costa, R., \& Moreno-Guerrero, A.J. (2020a). Arduino Advances in Web of Science. A Scientific Mapping of Literary Production. IEEE Access, 8, 128674128682. Doi: 10.1109/ACCESS.2020.3008572.

[42]. López-Belmonte, J., Moreno-Guerrero, A.J., Pozo-Sánchez, S., \& López-Núñez, J.A. (2020b). La Formación Profesional ante el reto de las TIC: Proyección de la realidad aumentada entre su profesorado y predictores de uso. Revista complutense de educación,31(4), 423-433. Doi: $10.5209 /$ rced.65443

[43]. López-Belmonte, J., Segura-Robles, A., Moreno-Guerrero, A.J., \& Parra-González, M.E. (2021a) Robotics in Education: A Scientific Mapping of the Literature in Web of Science. Electronics, 10(3), 118. Doi: 10.3390/electronics 10030291

[44]. López-Belmonte, J., Segura-Robles, A., Moreno-Guerrero, A.J., \& Parra-González, M.E. (2021b). Projection of E-Learning in Higher Education: A Study of Its Scientific Production in Web of Science. Eur. J. Investig. Health Psychol. Educ., 11(1), 20-32. Doi: 10.3390/ejihpe11010003

[45]. Maldonado, G.A., García, J., \& Sampedro-Requena, B. (2019). The effect of ICT and social networks on university students. RIED, 22, 153-176. Doi: 10.5944/ried.22.2.23178

[46]. Marín-Marín, J.A., Soler-Costa, R., Moreno-Guerrero, A.J., \& López-Belmonte, J. (2020a). Effectiveness of Diet Habits and Active Life in Vocational Training for Higher Technician in Dietetics: Contrast between the Traditional Method and the Digital Resources. Nutriens, 12(11), 3475. Doi: 10.3390/nu12113475

[47]. Marín-Marín, J.A., Soler-Costa, R., Moreno-Guerrero, A.J., \& López-Belmonte, J. (2020b). Makey Makey as an Interactive Robotic Tool for High School Students' Learning in Multicultural Contexts. Educ. Sci., 10(9), 239. Doi: 10.3390/educsci10090239

[48]. Mayer, R.E. (2020). Searching for the role of emotions in e-learning. Learning and Instruction, 70, 1-3. Doi: 10.1016/j.learninstruc.2019.05.010

[49]. Mian, A., \& Khan, S. (2020). Medical education during pandemics: A UK perspective. BMC Med., 18(100), 1-2. Doi: 10.1186/s12916-020-01577-y

[50]. Montilla, J.M., \& Kromrey, J. (2010). Robustez de las pruebas T en comparación de medias, ante violación de supuestos de normalidad y homocedasticidad. Ciencia e Ingeniería, 31, 101-108. Doi: 10.33262/cienciadigital.v2i4.1..187

[51]. Moreno-Guerrero, A.J., López-Belmonte, J., Marín-Marín, J.A., \& Soler-Costa, R. (2020a). Scientific development of educational artificial intelligence in web of science. Future Internet, 12(8), 124. Doi: 10.3390/fí12080124 
[52]. Moreno-Guerrero, A.J., Miaja-Chipirraz, N., Bueno-Pedrero, A., Borrego-Otero, L. (2020b). The Information and Information Literacy Area of the Digital Teaching Competence. Educare, 24(3), 1-16. Doi: $10.15359 /$ ree.24-3.25

[53]. Moreno-Guerrero, A.J., Rondón-García, M., Martínez-Heredia, N. \& Rodríguez-García, A.M. (2020c). Collaborative Learning Based on Harry Potter for Learning Geometric Figures in the Subject of Mathematics. Mathematics, 8(3), 369. Doi: 10.3390/math8030369

[54]. Moreno-Guerrero, A.J., Aznar-Díaz, I., Cáceres-Reche, P., \& Alonso-García, S. (2020d). E-Learning in the Teaching of Mathematics: An Educational Experience in Adult High School. Mathematics, 8(5), 840. Doi: $10.3390 /$ math 8050840

[55]. Moreno-Guerrero, A.J., Soler-Costa, R., Marín-Marín, J.A., \& López-Belmonte, J. (2021). Flipped learning y buenas prácticas docentes en educación secundaria. Comunicar, 29(68),1-11. doi: 10.3916/C68-2021-09

[56]. Moubayed, A., Injadat, M., Shami, A., \& Lutfiyya, H. (2020). Student Engagement Level in eLearning Environment: Clustering Using K-means. Am. J. Distance Educ., 34(2), 1-20. Doi: 10.1080/08923647.2020.1696140

[57]. Mousavi, A., Mohammadi, A., Mojtahedzadeh, R., Shirazi, M., \& Rashidi, H. (2020). E-learning educational atmosphere measure (EEAM): A new instrument for assessing e-students' perception of educational environment. Res. Learn. Technol., 28, 1-12. Doi: 10.25304/rlt.v28.2308

[58]. Movchun, V., Lushkov, R., \& Pronkin, N. (2020). Prediction of individual learning style in e-learning systems: opportunities and limitations in dental education. Education and Information Technologies, 115. Doi: 10.1007/s10639-020-10372-4

[59]. Mowla, S., \& Kolekar, S.V. (2020). Development and Integration of E-learning Services Using REST APIs. Int. J. Emerg. Technol. Learn., 15(4), 53-72

[60]. Msomi, A.M., \& Bansilal, S. (2018). The experiences for first-year students in mathematics in using an e-learning platform a University of Technology. South J. High. Educ., 32(5), 124-139

[61]. Mulqueeny, K., Kostyuk, V., Baker, R.S., \& Ocumpaugh, J. (2015). Incorporating effective e-learning principles to improve student engagement in middle-school mathematics. Int. J. STEM Educ., 2(15), 114. Doi: 10.1186/s40594-015-0028-6

[62]. Mutambik, I., Lee, J., \& Almuqrin, A. (2020). Role of gender and social context in readiness for elearning in Saudi high schools. Distance Education, 41(4), 515-539. Doi:10.1080/01587919.2020.1821602

[63]. Nasrullah, A., Marlina, M., \& Dwiyanti, W. (2018). Development of Student Worksheet-Based College E-Learning Through Edmodo to Maximize the Results of Learning and Motivation in Economic Mathematics Learning. Int. J. Emerg. Technol. Learn., 13(12), 211-229

[64]. Nikolopoulou, K., Akriotou, D., \& Gialamas, V. (2019). Early Reading Skills in English as a Foreign Language Via ICT in Greece: Early Childhood Student Teachers' Perceptions. Early Child. Educ. J., 47, 597-606. Doi: 10.1007/s10643-019-00950-8

[65]. Ozyurt, O., Ozyurt, H., Baki, A., \& Guven, B. (2013). Integration into mathematics classrooms of an adaptive and intelligent individualized e-learning environment: Implementation and evaluation of UZWEBMAT. Comput. Hum. Behav., 29(3), 726-738. Doi: 10.1016/j.chb.2012.11.013

[66]. Paechter, M., Macher, D., Martskvishvili, K., Wimmer, S., \& Papousek, I. (2017). Mathematics Anxiety and Statistics Anxiety. Shared but Also Unshared Components and Antagonistic Contributions to Performance in Statistics. Front. Psychol., 8, 1-13. Doi: 10.3389/fpsyg.2017.01196

[67]. Pereira, S., Fillol, J., \& Moura, P. (2019). El aprendizaje de los jóvenes con medios digitales fuera de la escuela: De lo informal a lo formal. Comunicar, 58(1), 41-50. Doi: 10.3916/C58-2019-04

[68]. Qian, Y. (2018). Application Research of E-learning Network Teaching Platform in College English Reading Teaching. Educ. Sci. -Theory \& Pract., 18(5), 1819-1827. Doi: 10.12738/estp.2018.5.082

[69]. Rajabalee, Y.B., \& Santally, M.I. (2020). Learner satisfaction, engagement and performances in an online module: Implications for institutional e-learning policy. Education and Information Technologies, 1-34. Doi: 10.1007/s10639-020-10375-1

[70]. Rakic, S., Tasic, N., Marjanovic, U., Softic, S., Luftenegger, E., \& Turcin, I. (2020). Student Performance on an E-Learning Platform: Mixed Method Approach. Int. J. Emerg. Technol. Learn., 15(2), 187-203. doi: 10.3991/ijet.v15i02.11646

[71]. Sathiyamoorthi, V. (2020). An Intelligent System for Predicting a User Access to a Web Based ELearning System Using Web Mining. Int. J. Inf. Technol. Web Eng., 15(1), 75-94. Doi: 10.4018/IJITWE.2020010106

[72]. Segura-Robles, A., Moreno-Guerrero, A.J., Parra-González, M.E., \& López-Belmonte, J. (2020). Review of Research Trends in Learning and the Internet in Higher Education. Soc. Sci., 9(6), 101. Doi: 10.3390/socsci9060101 
[73]. Semerci, Y.C., \& Goularas, D. (2020). Evaluation of Students' Flow State in an E-learning Environment Through Activity and Performance Using Deep Learning Techniques. Journal of Educational Computing Research, 1-28. Doi: 10.1177/0735633120979836

[74]. Shakah, G., Al-Oqaily, \& Alqudah, F. (2019). Motivation Path between the Difficulties and Attitudes of Using the E-Learning Systems in the Jordanian Universities: Aajloun University as a Case Study. Int. J. Emerg. Technol. Learn., 14(19), 26-48

[75]. Tan, S.M., Liew, T.W., \& Gan, C.L. (2020). Motivational virtual agent in e-learning: The roles of regulatory focus and message framing. Inf. Learn. Sci., 121, 37-51. Doi: 10.1108/ILS-09-2019-0088

[76]. Titilope, E.A., \& Idiong, U.S. (2017). Depression and anxiety: The bane of academic achievement among science students offering mathematics. Med Sci., 21(83), 8-15

[77]. Vagarinho, J.P., \& Llamas-Nistal, M. (2020). Process-Oriented Quality in e-Learning: A Proposal for a Global Model. IEEE Access, 8, 13710-13734. Doi: 10.1109/ACCESS.2020.2965619

[78]. Viktorova, L.V. (2020). Educational conditions for implementation of adults' distance learning of foreign languages. Inf. Technol. Learn. Tools, 75(1), 13-25

[79]. Waluyo, B. (2020). Learning Outcomes of a General English Course Implementing Multiple E-learning Technologies and Active Learning Concepts. J. Asia TEFL, 17(1), 160-181. Doi: 10.18823/asiatefl.2020.17.1.10.160

[80]. Wongwatkit, C., Panjaburee, P., Srisawasdi, N., \& Seprum, P. (2020). Moderating effects of gender differences on the relationships between perceived learning support, intention to use, and learning performance in a personalized e-learning. Journal of Computers in Education, 7, 229-255. Doi: 10.1007/s40692-020-00154-9

[81]. Wongwuttiwat, J., Buraphadeja, V., \& Tantontrakul, T. (2020). A case study of blended e-learning in Thailand. Interact. Technol. Smart Educ., 1-19. Doi: 10.1108/ITSE-10-2019-0068

[82]. Williamson, T. (2018). Alternative logics and applied mathematics. Philos. Issues, 28(1), 399-424. Doi: https://doi.org/10.1111/phis.12131

[83]. Yagci, E., \& Uluoz, T. (2018). Leadership Styles of School Administrators and its Relation with the Mobbing Experience Levels of Social, Science and Mathematics Teachers. Eurasia J. Math. Sci. Technol. Educ., 14(1), 155-166. Doi: 10.12973/ejmste/78061

[84]. Yaniawati, P., Kariadinata, R., Sarin, N.M., Pramiarsih, E.E., \& Mariani, M. (2020). Integration of eLearning for Mathematics on Resource-Based Learning: Increasing Mathematical Creative Thinking and Self-Confidence. Int. J. Emerg. Technol. Learn., 15(6), 60-78

[85]. Yawson, D.E. (2021). Gender variability in E-learning utility essentials: Evidence from a multigenerational higher education cohort. Computers in Human Behavior, 114, 1-14. Doi: 10.1016/j.chb.2020.106558

[86]. Yazdanfar, K., Beikzad, J., Rahimi, G., \& Bohlooni, N. (2021). Identifying and prioritizing effective factors of e-learning effectiveness using hierarchical analysis in the Ministry of Education in Iran. Apuntes Universitarios, 11, 429-449. Doi: 10.17162/au.v11i1.595

[87]. Zhou, Y.Z., Zhao, J., \& Zhang, J.J. (2020). Prediction of learners' dropout in E-learning based on the unusual behaviors. Interactive Learning Environments, 1-25. Doi: 10.1080/10494820.2020.1857788

[88]. Zhu, X., \& Chen, Z. (2020). Dual-modality spatiotemporal feature learning for spontaneous facial expression recognition in e-learning using hybrid deep neural network. Vis. Comput., 36, 743-755. Doi: 10.1007/s00371-019-01660-3 